Volume 02 Nomor 01, Juni 2020 Page 43-51

Incrementapedia: Jurnal Pendidikan Anak Usia Dini

Program Studi PG-PAUD Fakultas Pedagogik dan Psikologi

Universitas PGRI Adi Buana Surabaya

http://jurnal.unipasby.ac.id/index.php/incrementapedia

e-ISSN: 2686-3146

\title{
PENGARUH PERMAINAN KARTU GAMBAR \\ PADA PEMEROLEHAN KOSA KATA \\ ANAK USIA 5-6 TAHUN
}

\author{
Nur laili Mus'adah ${ }^{\text {a, }}$ Ahmad Fachrurrazi ${ }^{\text {b }}$ \\ a,bPG-PAUD, Fakultas Pedagogik dan Psikologi Universitas PGRI Adi Buana Surabaya \\ nurlailimusadah@gmail.com, ahmadfachrurrazi@unipasby.ac.id
}

\begin{abstract}
Picture card games are one type of game that can support early childhood education in aspects of language development to improve the acquisition of children's vocabulary. Mastery of vocabulary has an important function, because children who master a lot of vocabulary, tend to have high self-esteem. The purpose of this study is to describe more in-depth about the effect of picture card games on the acquisition of children's vocabulary. The method used is a quantitative research method using the design of the One Group PretestPosttest. Sempel used in this study were 19 children in group B TK Aisyiyah Bustanul Athfal 57 Surabaya. Data were collected from the results of performance test observations, with a performance sheet observation instrument. The data analysis technique uses the t test formula.The results of this study indicate that $t$ count obtained value (36.66) greater than the value of t table (1.79) at the significance level of 0.05 and (2.55) at the 0.01 significance level, then the Zero Hypothesis is rejected so the Hypothesis Work received. Thus it can be stated that "there is a positive influence between the activity of playing a picture card on the acquisition of children's vocabulary
\end{abstract}

Keywords: Picture card games, vocabulary acquisition.

\section{PENDAHULUAN}

Usia dini merupakan periode yang sangat penting dalam kehidupan manusia. Pada masa ini, kecerdasan dan kecakapan prakis anak akan tumbuh dan berkembang dengan baik melalui stimulasi yang diberikan. Oleh karena itu diperlukan upaya yang mampu mendukung pertumbuhan dan perkembangan anak dengan memfasilitasi anak melalui kegiatan pendidikan dan pembelajaran sesuai dengan tahapan usia, kebutuhan dan minat anak.

Suyadi (2010:296-297) menyatakan bahwa, ketika anak sedang bermain, tanpa disadari anak belajar keras untuk dapat memerankan dirinya dalam permainan tersebut yang dapat meningkatkan berbagai aspek kecerdasan anak. Selain itu melalui kegiatan bermain anak dapat belajar dengan baik tanpa ada paksaan dan tekanan. Carron \& Jon dalam Perdani (2013:340) menyatakan bahwa, bermain merupakan suatu sarana yang dapat mempengaruhi seluruh aspek perkembangan anak dengan memberikan kesempatan kepada anak untuk belajar tentang dirinya sendiri, orang lain, lingkungan dan dapat memberikan kebebasan kepada anak untuk berimajinasi, bereksplorasi dan kreatif, sehingga anak dapat berkembang secara optimal.

Menurut Sumantri dan Syaodih (2009:2.30), bahasa adalah segala bentuk komunikasi dimana pikiran dan perasaan seseorang disimbilisasikan agar dapat menyampaikan arti kepada orang lain. 
Menurut Mulyasa (2012:116), bahasa adalah kemampuan untuk mengepresikan apa yang dialami dan dipikirkan oleh anak dan kemampuan untuk menangkap pesan dari lawan bicara. Menurut Susanto (2012:74), bahasa adalah alat untuk berpikir, mengekspresikan diri dan berkomunikasi. Belajar bahasa untuk anak usia dini diarahkan pada kemampuan berkomunikasi, baik secara lisan maupun tertulis.

Penguasaan kosa kata adalah kegiatan menguasai atau kemampuan memahami dan menggunakan kata-kata yang terdapat dalam satu bahasa, baik bahasa lisan maupun tertulis, (Elviza dkk 2013:469). Sehingga penggunaan kosa kata sangat diperlukan karena semakin banyaknya kosa kata yang diperoleh, semakin mudah pula seseorang untuk menyampaikan dan menerima informasi yang masuk. Masa anak-anak merupakan masa pesatnya pengembangan kosa kata. Karena pada masa ini merupakan masa emas anak untuk mengembangkan aspek perkembangannya. Kosa kata yang dikuasai anak mempunyai kaitan erat dengan pestasi sekolah secara keseluruhan (Robbins dan Ehri dalam Irenaningtyas dan Wulan, 2004:92). Dengan kemampuan pemerolehan kosa kata yang tinggi sangat mendukung anak dalam mengembangkan aspek perkembangan lainnya.

Penguasaan kosa kata memiliki fungsi yang amat penting dalam perkembangan anak, karena anak yang menguasai banyak kosa kata, cenderung memiliki rasa percaya diri dan dapat mempengaruhi teman sebaya untuk bertingkah laku seperti yang diharapkannya daripada anak yang memiliki pemerolehan kosa kata rendah,
(Hamboro dalam Irenaningtyas dan Wulan, 2004:92).

Untuk mengembangkan kemampuan bahasa permula anak usia dini dibutuhkan rangsangan atau stimulasi yang berasal dari lingkungan, khususnya seperti sekolah. Dalam kegiatan di TK dilakukan dengan kegiatan belajar sambil bermain yang menggunakan media yang menarik sehingga anak memiliki rasa ingin bermain. Sehingga proses pembelajaran anak dapat berjalan dengan optimal. Salah satu permainan yang mudah untuk membantu anak memperoleh kosa kata banyak adalah permainan kartu gambar (Hasan,2012:335). Permainan kartu gambar adalah salah satu jenis permainan yang dapat mendukung pendidikan anak usia dini dalam aspek perkembangan bahasa yang mampu meningkatkan pemerolehan kosa kata anak.

Berdasarkan penelitian yang dilakukan oleh Novianti dari Universitas Negeri Jakarta, (2013) yang berjudul "Pengaruh Permainan Kartu Gambar dan Kecerdasan Linguistik terhadap Kemampuan Membaca Pemulaan" terdapat interaksi antara permainan kartu gambar dan kecerdasan linguistik terhadap kemampuan membaca pemulaan anak. Melalui permainan kartu bergambar lebih baik daripada anak yang diberikan permainan kartu huruf bergambar. menurut penelitian yang dilakukan oleh Fatwikiningsih dari Universitas Muhammadiyah Malang, (2014) yang berjudul "Peningkatan Kemampuan Berbahasa Melalui Metode Berkomunikasi Dengan Gambar Pada Anak Dengan Ciri Gangguan Pemusatan Perhatian dan Hiperaktivitas". bahwa metode berkomunikasi dengan gambar berpengaruh terhadap kemampuan berbahasa ekspresif dan reseptik anak pra sekolah 
yang mempunyai ciri GPPH sub tipe kurang konsentrasi. Sedangkan menurut penelitian yang dilakukan oleh Mariati, dkk dari Universitas Pendidikan Ganesha Singaraja, (2014) yang berjudul "Penerapan Model Picture and Picture Berbantuan Media Kartu Gambar Untuk Meningkatkan Kemampuan Bahasa Di TK KUMALA PATAHAN" bahwa penerapan media kartu gambar untuk meningkatkan kemampuan bahasa anak ternyata efektif. Sehingga perkembangan aspek bahasa anak meningkat perkembangannya.

Atas dasar tinjauan hasil penelitian di atas dapat disimpulkan bahwa permainan kartu gambar sangat penting dalam mengembangkan aspek perkembangan bahasa anak. Melalui permainan kartu gambar meningkatkan anak dalam kemampuan membaca pemula serta kemampuan berbahasa anak menjadi efektif. Karena permainan kartu gambar bisa dijadika metode berkomunikasi. Apabila kemampuan berbahasa anak baik, kemampuan pemerolehan kosa kata yang dimiliki anak pasti banyak. Dengan demikian dapat disimpulkan bahwa permainan kartu gambar dapat meningkatkan kemampuan pemerolehan kosa kata anak.

\section{METODE PENELITIAN}

Penelitian ini menggunakan desain uji beda hasil pre test dan pos test untuk satu kelompok yang disebut one group pre and post test design. Rancangan penelitiannya sebagai berikut.

$$
\mathrm{O}_{1} \mathrm{X} \mathrm{O}_{2}
$$

Keterangan:

$\mathrm{O}_{1}$ : Pre test, $\mathrm{X}$ : Perlakuan,
$\mathrm{O}_{2}$ : Post test.

Populasi dan sampel yang diambil peneliti adalah anak kelompok B TK ABA Semolowaru Surabaya. Adapun Variable yang digunakan dalam penelitian ini adalah variable independen dan variable dependen. Variable independen pada penelitian ini yaitu kegiatan berbasis literasi dan variabel dependen adalah kemampuan berbahasa anak.

Perangkat pembelajaran yang digunakan dalam penelitian ini adalah RPPM (Rencana Pelaksanaan Pembelajaran Mingguan) dan RPPH (Rencana Pelaksanaan Pembelajaran Harian).

Untuk menguji hipotesis yang sudah ditetapkan peneliti menggunakan teknik analisis statistik inferensial dengan teknik uji beda pre-test dan post-test dalam satu kelompok yang disebut uji $\mathrm{t}$ onegroup pre and post test.

\section{HASIL PENELITIAN}

Perbedaan hasil pre test dan post test dari subyek penelitian tergambar seperti pada tabel berikut.

Tabel 1Uji Beda'Pre test-Post test 


\begin{tabular}{|c|c|c|c|}
\hline Subyek & Pre-Test & Post-Test & Gain \\
\hline 1 & 2,58 & 3,33 & 0,75 \\
\hline 2 & 2,54 & 3,29 & 0,75 \\
\hline 3 & 2,75 & 3,54 & 0,79 \\
\hline 4 & 2,75 & 3,42 & 0,67 \\
\hline 5 & 2,88 & 3,54 & 0,67 \\
\hline 6 & 2,83 & 3,50 & 0,67 \\
\hline 7 & 2,79 & 3,58 & 0,79 \\
\hline 8 & 2,46 & 3,42 & 0,96 \\
\hline 9 & 2,88 & 3,58 & 0,71 \\
\hline 10 & 2,63 & 3,46 & 0,83 \\
\hline 11 & 2,88 & 3,50 & 0,63 \\
\hline 12 & 2,50 & 3,29 & 0,79 \\
\hline 13 & 2,83 & 3,71 & 0,88 \\
\hline 14 & 2,83 & 3,46 & 0,63 \\
\hline 15 & 3,21 & 3,92 & 0,71 \\
\hline 16 & 2,67 & 3,46 & 0,79 \\
\hline 17 & 2,88 & 3,71 & 0,83 \\
\hline 18 & 2,96 & 3,63 & 0,67 \\
\hline 19 & 2,88 & 3,67 & 0,79 \\
\hline \multicolumn{4}{|l|}{ Jumlah } \\
\hline 19 & 52,71 & 67,00 & \\
\hline Rerata: & 2,77 & 3,53 & 14,29 \\
\hline \multicolumn{4}{|c|}{ ( $T_{\text {hitung }}$ ) seperti tertera pada tabel berikut. } \\
\hline \multicolumn{4}{|c|}{ Tabel 2. Uji signifikansi T-test (Thitung) } \\
\hline Subyek & d & $\mathrm{X}_{\mathrm{d}=(\mathrm{d}-\mathrm{Md})}$ & $\mathrm{x}_{\mathrm{d}}^{2}$ \\
\hline 1 & 0,75 & 0,00 & 0,00 \\
\hline 2 & 0,75 & 0,00 & 0,00 \\
\hline 3 & 0,79 & 0,04 & 0,00 \\
\hline 4 & 0,67 & $-0,09$ & 0,01 \\
\hline 5 & 0,67 & $-0,09$ & 0,01 \\
\hline 6 & 0,67 & $-0,09$ & 0,01 \\
\hline 7 & 0,79 & 0,04 & 0,00 \\
\hline 8 & 0,96 & 0,21 & 0,04 \\
\hline 9 & 0,71 & $-0,04$ & 0,00 \\
\hline 10 & 0,83 & 0,08 & 0,01 \\
\hline 11 & 0,63 & $-0,13$ & 0,02 \\
\hline 12 & 0,79 & 0,04 & 0,00 \\
\hline 13 & 0,88 & 0,12 & 0,02 \\
\hline 14 & 0,63 & $-0,13$ & 0,02 \\
\hline 15 & 0,71 & $-0,04$ & 0,00 \\
\hline 16 & 0,79 & 0,04 & 0,00 \\
\hline 17 & 0,83 & 0,08 & 0,01 \\
\hline 18 & 0,67 & $-0,09$ & 0,01 \\
\hline 19 & 0,79 & 0,04 & 0,00 \\
\hline \multicolumn{4}{|l|}{ jumlah } \\
\hline 19 & 14,29 & 0,00 & 0,14 \\
\hline
\end{tabular}

Ringkasan hasil uji hipotesis seperti tertera pada tabel berikut.

Tabel 3. Ringkasan hasil uji hipotesis

\begin{tabular}{lccccc}
\hline \multicolumn{1}{c}{ Hipotesis } & Signifikansi & $\mathrm{t}_{\text {hitung }}$ & $\mathrm{t}_{\text {tabel }}$ & $\mathrm{H}_{0}$ & $\mathrm{H}_{1}$ \\
Permainan kartu & 0,05 & 36,66 & 1,79406 & ditolak & diterima \\
gambar & 0,01 & & 2,55238 & \\
berpengaruh pada & & & & \\
pemerolehan & & & & \\
kosakata anak & & & & \\
kelompok B TK & & & & \\
Aisyiyah Bustanul & & & & \\
Athfal 57 & & & & \\
Surabaya. & & & & \\
\hline
\end{tabular}

Dari tabel di atas dapat diketahui bahwa nilai $\mathrm{t}$ tabel lebih kecil daripada nilai t hitung baik pada taraf signifikansi 0,05 maupun pada taraf signifikansi 0,01. Dengan demikian Hipotesis Nol ditolak sehingga Hipotesis Kerja diterima. Dari tabel tersebut juga dapat diketahui bahwa nilai $\mathrm{t}$ hitung jauh lebih besar daripada nilai t tabel pada kedua taraf signifikansi itu, maka dapat dikatakan bahwa Hipotesis Kerja terbukti dengan sangat signifikan. Dengan demikian dapat dikatakan juga bahwa permainan kartu bergambar berpengaruh pada pemerolehan kosa kata anak.

\section{PEMBAHASAN}

Dari data yang terkumpul dan dari hasil perhitungan data setiap treatment dapat diketahui atau menunjukkan bahwa peningkatan pemerolehan kosa kata setelah dilakukan perlakuan dengan permainan kartu gamba. Hal ini dibuktikan pada treatment 1 dari 19 anak sebelum adanya perlakuan (Pre Test) pada indikator (1) Kemampuan anak dalam menjawab gambar yang ditunjukkan pada kartu gambar, yang mulai berkembang ada 14 anak dan yang berkembang sesuai harapan ada 5 anak. Pada indikator (2) Kemampuan anak dalam memahami gambar, yang mulai berkembang ada 7 anak dan yang berkembang sesuai harapan ada 12 anak. Dan pada indikator (3) jumlah kosa kata dalam menjawab 
gambar, yang mulai berkembang ada 18 anak dan yang berkembang sesuai harapan ada 1 anak. Sedangkan hasil setelah adanya perlakuan (Pots Test) pada indikator (1)) Kemampuan anak dalam menjawab gambar yang ditunjukkan pada kartu gambar, yang berkembang sesuai harapan ada 13 anak dan yang berkembang sangat baik ada 6 anak. Pada indikator (2) Kemampuan anak dalam memahami gambar, yang berkembang sesuai harapan ada 6 anak dan yang berkembang sangat baik ada 13 anak.Dan pada indikator (3) jumlah kosa kata dalam menjawab gambar, yang berkembang sesuai harapan ada 18 dan yang berkembang sangat baik ada 1 anak. Dengan demikian pada treatment 1 dapat dikatakan adanya peningkatan setelah perlakuan.

Pada treatment 2 dari 19 anak sebelum adanya perlakuan (Pre Test) pada indikator (1) Kemampuan anak dalam menjawab gambar yang ditunjukkan pada kartu gambar, yang mulai berkembang ada 4 anak dan yang berkembang sesuai harapan ada 15 anak. Pada indikator (2) Kemampuan anak dalam memahami gambar, yang mulai berkembang ada 1 anak dan yang berkembang sesuai harapan ada 18 anak. Dan pada indikator (3) jumlah kosa kata dalam menjawab gambar, yang mulai berkembang ada 8 anak dan yang berkembang sesuai harapan ada 11 anak. Sedangkan hasil setelah adanya perlakuan(Pots Test) pada indikator (1) Kemampuan anak dalam menjawab gambar yang ditunjukkan pada kartu gambar, yang berkembang sesuai harapan ada 5 anak dan yang berkembang sangat baik ada 14 anak. Pada indikator (2) Kemampuan anak dalam memahami gambar, yang berkembang sesuai harapan ada 3 anak dan yang berkembang sangat baik ada 16 anak.Dan pada indikator (3) jumlah kosa kata dalam menjawab gambar, yang berkembang sesuai harapan ada 6 dan yang berkembang sangat baik ada 13 anak. Dengan demikian pada treatment 2 dapat dikatakan adanya peningkatan setelah perlakuan.

Pada treatment 3 dari 19 anak sebelum adanya perlakuan (Pre Test) pada indikator (1) Kemampuan anak dalam menjawab gambar yang ditunjukkan pada kartu gambar, yang mulai berkembang ada 9 anak dan yang berkembang sesuai harapan ada 10 anak. Pada indikator (2) Kemampuan anak dalam memahami gambar, yang mulai berkembang ada 5 anak dan yang berkembang sesuai harapan ada 14 anak. Dan pada indikator (3) jumlah kosa kata dalam menjawab gambar, yang mulai berkembang ada 13 anak dan yang berkembang sesuai harapan ada 6 anak. Sedangkan hasil setelah adanya perlakuan(Pots Test) pada indikator (1) Kemampuan anak dalam menjawab gambar yang ditunjukkan pada kartu gambar, yang berkembang sesuai harapan ada 18 anak dan yang berkembang sangat baik ada 1 anak. Pada indikator (2) Kemampuan anak dalam memahami gambar, yang berkembang sesuai harapan ada 3 anak dan yang berkembang sangat baik ada 16 anak.Dan pada indikator (3) jumlah kosa kata dalam menjawab gambar, yang berkembang sesuai harapan ada 17 dan yang berkembang sangat baik ada 2 anak. Dengan demikian pada treatment 3 dapat dikatakan adanya peningkatan setelah perlakuan.

Pada treatment 4 dari 19 anak sebelum adanya perlakuan (Pre Test) pada indikator (1) Kemampuan anak dalam menjawab gambar yang ditunjukkan pada kartu gambar, yang mulai 
berkembang ada 1 anak, yang berkembang sesuai harapan ada 13 anak dan yang berkembang sangat baik ada 5 anak. Pada indikator (2) Kemampuan anak dalam memahami gambar, yang mulai berkembang ada 1 anak, yang berkembang sesuai harapan ada 16 anak dan yang berkembang sangat baik ada 2 anak. Dan pada indikator (3) jumlah kosa kata dalam menjawab gambar, yang mulai berkembang ada 7 anak dan yang berkembang sesuai harapan ada 12 anak. Sedangkan hasil setelah adanya perlakuan (Pots Test) pada indikator (1) Kemampuan anak dalam menjawab gambar yang ditunjukkan pada kartu gambar, yang berkembang sesuai harapan ada 5 anak dan yang berkembang sangat baik ada 14 anak. Pada indikator (2) Kemampuan anak dalam memahami gambar, yang berkembang sesuai harapan ada 2 anak dan yang berkembang sangat baik ada 17 anak.Dan pada indikator (3) jumlah kosa kata dalam menjawab gambar, yang berkembang sesuai harapan ada 11 dan yang berkembang sangat baik ada 8 anak. Dengan demikian pada treatment 4 dapat dikatakan adanya peningkatan setelah perlakuan.

Pada treatment 5 dari 19 anak sebelum adanya perlakuan (Pre Test) pada indikator (1) Kemampuan anak dalam menjawab gambar yang ditunjukkan pada kartu gambar, yang mulai berkembang ada 1 anak, yang mulai berkembang ada 3 anak dan yang berkembang sesuai harapan ada 16 anak. Pada indikator (2) Kemampuan anak dalam memahami gambar, yang mulai berkembang ada 2 anak, yang berkembang sesuai harapan ada 16 anak dan yang berkembang sangat baik ada 1 anak. Dan pada indikator (3) jumlah kosa kata dalam menjawab gambar, yang mulai berkembang ada 10 anak dan yang berkembang sesuai harapan ada 9 anak. Sedangkan hasil setelah adanya perlakuan (Pots Test) pada indikator (1) Kemampuan anak dalam menjawab gambar yang ditunjukkan pada kartu gambar, yang berkembang sesuai harapan ada 11 anak dan yang berkembang sangat baik ada 8 anak. Pada indikator (2) Kemampuan anak dalam memahami gambar, yang berkembang sesuai harapan ada 6 anak dan yang berkembang sangat baik ada 13 anak. Dan pada indikator (3) jumlah kosa kata dalam menjawab gambar, semua anak berkembang sesuai harapan. Dengan demikian pada treatment 5 dapat dikatakan adanya peningkatan setelah perlakuan.

Pada treatment 6 dari 19 anak sebelum adanya perlakuan (Pre Test) pada indikator (1) Kemampuan anak dalam menjawab gambar yang ditunjukkan pada kartu gambar dan indikator (2) Kemampuan anak dalam memahami gambar, semua anak berkembang sesuai harapan. Dan pada indikator (3) jumlah kosa kata dalam menjawab gambar, yang mulai berkembang ada 2 anak, yang berkembang sesuai harapan ada 14 anak, dan yang berkembang sangat baik ada 2 anak. Sedangkan hasil setelah adanya perlakuan (Pots Test) pada indikator (1) Kemampuan anak dalam menjawab gambar yang ditunjukkan pada kartu gambar, yang berkembang sesuai harapan ada 8 anak dan yang berkembang sangat baik ada 11 anak. Pada indikator (2) Kemampuan anak dalam memahami gambar, yang berkembang sesuai harapan ada 11 anak dan yang berkembang sangat baik ada 8 anak.Dan pada indikator (3) jumlah kosa kata dalam menjawab gambar, yang berkembang sesuai harapan ada 13 dan yang berkembang sangat baik ada 7 anak. Dengan demikian pada treatment 6 
dapat dikatakan adanya peningkatan setelah perlakuan.

Pada treatment 7 dari 19 anak sebelum adanya perlakuan (Pre Test) pada indikator (1) Kemampuan anak dalam menjawab gambar yang ditunjukkan pada kartu gambar, yang mulai berkembang ada 1 anak dan yang berkembang sesuai harapan ada 18 anak. Pada indikator (2) Kemampuan anak dalam memahami gambar, yang mulai berkembang ada 1 anak dan yang berkembang sesuai harapan ada 18 anak. Dan pada indikator (3) jumlah kosa kata dalam menjawab gambar, yang mulai berkembang ada 2 anak, yang berkembang sesuai harapan ada 13 anak dan yang berkembang sangat baik ada 4 anak. Sedangkan hasil setelah adanya perlakuan (Pots Test) pada indikator (1) Kemampuan anak dalam menjawab gambar yang ditunjukkan pada kartu gambar, yang berkembang sesuai harapan ada 10 anak dan yang berkembang sangat baik ada 9 anak. Pada indikator (2) Kemampuan anak dalam memahami gambar, yang berkembang sesuai harapan ada 5 anak dan yang berkembang sangat baik ada 13 anak, Dan pada indikator (3) jumlah kosa kata dalam menjawab gambar, yang berkembang sesuai harapan ada 12 dan yang berkembang sangat baik ada 7 anak. Dengan demikian pada treatment 7 dapat dikatakan adanya peningkatan setelah perlakuan.

Pada treatment 8 dari 19 anak sebelum adanya perlakuan (Pre Test) pada indikator (1) Kemampuan anak dalam menjawab gambar yang ditunjukkan pada kartu gambar dan indikator (2) Kemampuan anak dalam memahami gambar, semua anak berkembang sesuai harapan. Dan pada indikator (3) jumlah kosa kata dalam menjawab gambar, yang mulai berkembang ada 8 anak, yang berkembang sesuai harapan ada 10 anak, dan yang berkembang sangat baik ada 1 anak. Sedangkan hasil setelah adanya perlakuan (Pots Test) pada indikator (1) Kemampuan anak dalam menjawab gambar yang ditunjukkan pada kartu gambar, yang berkembang sesuai harapan ada 5 anak dan yang berkembang sangat baik ada 14 anak. Pada indikator (2) Kemampuan anak dalam memahami gambar, yang berkembang sesuai harapan ada 2 anak dan yang berkembang sangat baik ada 17 anak.Dan pada indikator (3) jumlah kosa kata dalam menjawab gambar, yang berkembang sesuai harapan ada 11 dan yang berkembang sangat baik ada 8 anak. Dengan demikian pada treatment 8 dapat dikatakan adanya peningkatan setelah perlakuan.

Dari data yang terkumpul mulai treatment 1 sampai treatment 8 dan dari hasil perhitungan data dapat diketahui bahwa peningkatan pemerolehan kosa kata setelah dilakukan perlakuan dengan permainan kartu gambar memiliki pengaruh dengan peningkatan (Pro Test) sebesar 3,53 sedangkan skor sebelum diberi perlakuan permainan kartu gambar (Post Test) sebesar 2,77. Dan berdasarkan uji thitung diperoleh nilai $(36,66)$ lebih besar daripada nilai t tabel $(1,79406)$ pada taraf signifikansi 0,05 dan $(2,55238)$ pada taraf signifikansi 0,01, maka hipotesis nol ditolak sehingga hipotesis kerja diterima. Hal ini terbukti Hipotesis Kerja terbukti dengan sangat signifikan. Dengan demikian dapat dinyatakan bahwa "ada pengaruh yang positif antara kegiatan bermain kartu gambar terhadap pemerolehan kosa kata anak usia 5-6 tahun. 


\section{SIMPULAN DAN SARAN}

\subsection{Simpulan}

Berdasarkan rumusan masalah dan tujuan penelitian yang telah dirumuskan yaitu "apakah ada pengaruh kegiatan bermain kartu gambar terhadap pemerolehan kosa kata anak usia 5-6 tahun (kelompok B) TK Aisyiyah Bustanul Athfal 57 Surabaya? diperkuat dengan uji hipotesis dimana diperoleh nilai $t_{\text {hitung }}(36,66)$ lebih besar daripada nilai tabel $(1,79406)$ pada taraf signifikansi 0,05 dan $(2,55238)$ pada taraf signifikansi 0,01 , yang bermakna hipotesis nol ditolak sehingga hipotesis kerja diterima dan terbukti dengan sangat signifikan, maka dapat disimpulkan bahwa "ada pengaruh yang positif antara kegiatan bermain kartu gambar terhadap pemerolehan kosa kata anak usia 5-6 tahun (kelompok B) TK Aisyiyah Bustanul Athfal 57 Surabaya.

\subsection{Saran}

Berdasarkan hasil penelitian penulis memberikan beberapa saran sebagai berikut.

a. Bagi Guru

Sebagai bahan referensi untuk dapat mengetahui bahwa kegiatan bermain kartu gambar sangat baik untuk meningkatkan pemerolehan kosakata anak usia dini. Guru harus menjadi motivator bagi anak dan dapat menciptakan model pembelajaran yang menarik bagi anak, sehingga kemampuan berbahasa anak berkembang secara optimal.

\section{b. Bagi Sekolah}

Sekolah diharapkan menyediakan sarana pembelajaran yang menunjang kegiatan belajar anak yang berkaitan dengan kemampuan meningkatkan pmerolehan kosakata anak. Salah satu sarana yang diperlukan adalah permainan kartu gambar, yang dapat memberikan stimulasi yang baik ketika anak bermain.

c. Bagi Orangtua

Memberi motivasi pada anak dengan meningkatkan pemerolehan kosakata anak dan dilakukan dengan cara bermain agar anak ketika belajar lebih menyenangkan dan tidak bosan.

\section{REFERENSI}

Elviza, Yulia dkk. (2013). Peningkatan Penguasaan Kosakata Melalui Tektik Permainan Teka-teki Silang Di Kelas VII A SMPN 2 Sungai Penuh. Dalam jurnal Pendidikan Bahasa dan Sastra Indonesia. Vol 1 (2):226-476.

Fatwikiningsih, Nur. (2014). Peningkatan Kemampuan Berbahasa Melalui Metode Berkomunikasi Dengan Gambar Pada Anak Dengan Ciri Gangguan Pemusatan Perhatian dan Hiperaktivitas. Dalam jurnal Sains dan Praktik Psikologi. Vol 2 (3):226-242.

Irenaningtyas, Dwi Astuti dan Wulan, Ratna. (2004). Perbedaan Penguasaan Kosakata Anak Pra-sekolah. Dalam jurnal Psikologi. No 2: 92:102.

Hasan, Maimunah.(2012). Pendidikan Anak Usia Dini. Jogjakarta: Diva Press.

Mulyasa. (2012). Manajemen PAUD. Bandung: PT Remaja Rosdakarya.

Marianti, Ni Made Evi dkk. (2014). Penerapan Mpdel Picture and Picture Berbantuan Media Kartu Gambar Untuk Meningkatkan Kemampuan Berbahasa Di TK DARMA KUMALA Penatahan. Dalam jurnal PDPAUD Universitas Pendidiksn Ganesha. Vol 2, No 1.

Novianti, Rahmah. (2013). Pengaruh Permainan Kartu Gambar dan Kecerdasan Linguistik Terhadap Kemampuan Membaca Permulaan. Dalam jurnal Pendidikan Usia Dini. Vol 7, Edisi 2.

Perdani, Putra Admi. (2013). Peningkatan Keterampilan Sosial Melalui Metode Bermain Permainan Tradisional Pada Anak TK B. Dalam jurnal Pendidikan Anak Usia Dini. Vol 7 Edisi 2.

Sumantri, Mulyani dan Syaodih, Nana. (2009). Perkembangan Peserta Didik. Jakarta: Universitas Terbuka. 
Susanto, Ahmad. (2012). Perkembangan Anak Usia Dini. Jakarta: KENCANA

Suyadi. (2010). Psikologi Belajar Paud.

Yogyakarta: PT Pustaka Insan Madani. 